\title{
Intracranial haemorrhage in haemophilia
}

\author{
C. B. KERR ${ }^{1}$ \\ From the Department of Medicine, University of Sydney, Australia
}

Intracranial bleeding has long been regarded as particularly lethal in haemophilia and is currently the most common cause of death among haemophiliacs in Finland (Ikkala, 1960), in Sweden (Blombäck, 1962), and in New South Wales (Kerr, 1963). It appears that intracranial haemorrhage has not been influenced by modern therapy to the same extent as post-operative or traumatic bleeding at other sites, which were formerly the most common causes of death (Birch, 1937). This trend is illustrated in Table I which shows the distribution of causes of death among 106 haemophiliacs in New South Wales between 1900 and 1962. Even allowing for incomplete ascertainment of deaths during the earlier years of this century, the threefold increase in fatal intracranial bleeding since 1940 contrasts with reduced mortality from most other types of haemorrhage during the same period.

\section{TABLE I}

DISTRIBUTION OF CAUSES OF DEATH ${ }^{1}$ IN 106 HAEMOPHILIACS $^{2}$ BEFORE AND AFTER 1940

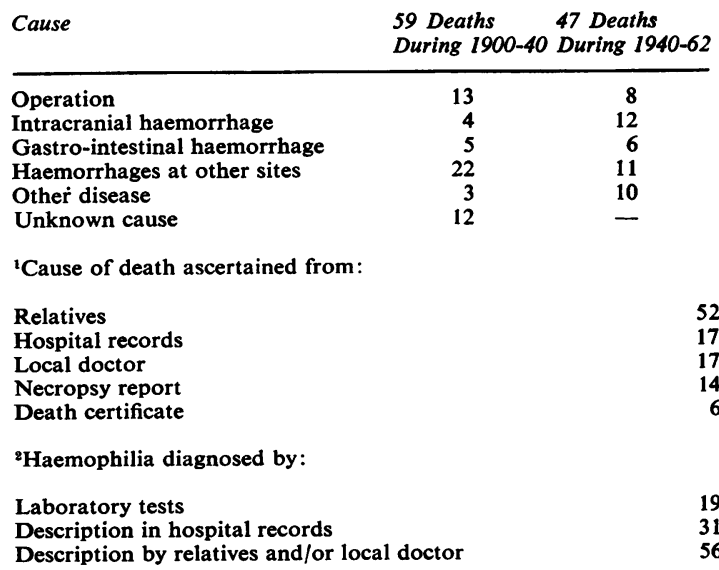

It is often impossible to be sure of the exact nature and location of intracranial lesions in haemophiliacs because of the difficulty in perform-

'Present address: M.R.C. Population Genetics Research Unit, Old Road, Headington, Oxford ing routine neuro-diagnostic procedures without considerable risk of provoking disastrous bleeding. $\frac{\overline{ }}{\bar{N}}$ This has led previous reviewers (Aggeler and Lucia, $\frac{\bar{C}}{\rightarrow}$ 1944; Imhof, 1951; Silverstein, 1960) to rely on å biased selection of cases where the diagnosis of ${ }_{\mathscr{O}}^{\circ}$ haemorrhage was proved at necropsy, operation, or lumbar puncture. As a result their conclusions weredirected more towards fatal intracranial bleeding $\vec{\omega}$ rather than episodes from which patients recovered. But in looking through case notes of haemophiliacs discovered in large population surveys (e.g., Sköldo 1944; Ikkala, 1960) it is not uncommon to encounter patients who had recovered from a serious neurological illness which was at the time attributed to $\overrightarrow{\text { s }}$ cerebral haemorrhage. So despite similar diagnostic restrictions an attempt has been made to study alP episodes of probable or proven intracranta $\square$ haemorrhage in a relatively large group of haengo philiacs.

\section{CLINICAL MATERIAL}

One hundred and nine haemophiliacs attended Roya? Prince Alfred Hospital, Camperdown, N.S.W., fop treatment during the five-year period January 1957 ton June 1962. As distinguished by the thromboplasting generation test, $91(83+)$ had factor VIII, anti-haemo philic globulin (A.H.G.) deficiency, and $17(16 \%)$ facto $\overrightarrow{5}$ IX, Christmas factor, deficiency. Dr.J. Margolis measure $\mathrm{B}$ coagulation factor levels in several patients with his micromethod (Margolis, 1961). There was good correlae tion between the estimated factor level and the severity of haemophilia determined on clinical grounds. Fo 5 descriptive purposes the term 'haemophilia' has been used to cover the clinically identical states of factors VIII and IX deficiency and the following gradations of severity were defined.

SEVERE HAEMOPHILIA The factor level is $0-1 \%$ of average normal level and the whole blood coagulation time is prolonged over 30 minutes; numerous haemorrhages from an early age; haemarthroses are invariable; cyclica麦: heightened potentiality to bleed ('bleeding phase') if usually marked.

MODERATE HAEMOPHILIA The factor level is $1-3 \%$ స్ Coagulation time is prolonged but not necessarily ove 30 minutes. An intermediate grade between severe an 6 
TABLE II

NINETEEN EPISODES OF PROVEN OR PROBABLE INTRACRANIAL HAEMORRHAGE

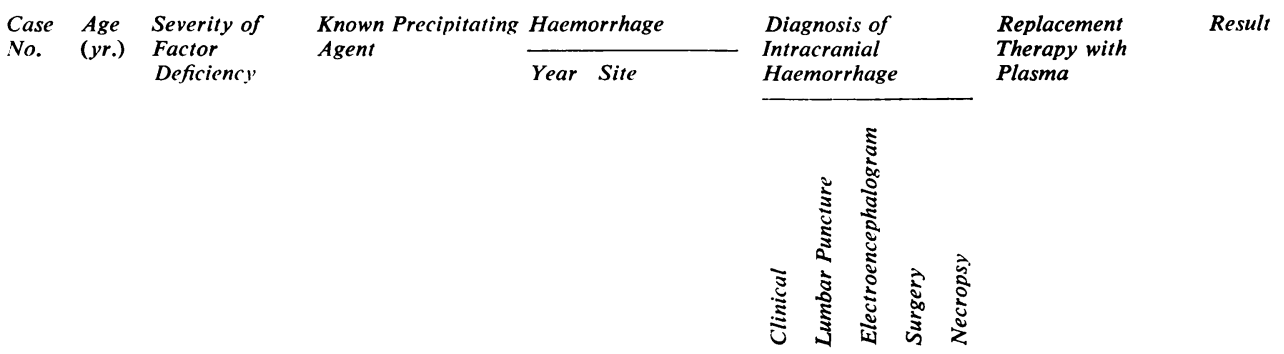

\begin{tabular}{|c|c|c|c|c|c|c|c|c|c|c|c|c|c|}
\hline 1 & 47 & VIII & severe & Aneurysm & 1957 & Mid-brain & - & - & - & - & + & Nil & Death \\
\hline 2 & 49 & IX & mild & Trauma & 1960 & $\begin{array}{l}\text { Subdural, } \\
\text { intracerebral }\end{array}$ & + & 一 & - & + & + & Adequate & Death \\
\hline \multirow[t]{2}{*}{3} & 48 & IX & mild & Nitroglycerine & 1959 & $\begin{array}{l}\text { Subarachnoid, } \\
\text { intracerebral }\end{array}$ & + & + & + & - & - & Adequate & Recovery \\
\hline & 50 & IX & mild & $\mathrm{Nil}$ & 1961 & Intracerebral & + & - & - & - & - & Nil & Death \\
\hline 4 & 43 & VIII & severe & Nil & 1958 & $\begin{array}{l}\text { Subarachnoid, } \\
\text { intracerebral }\end{array}$ & + & - & + & 一 & - & Adequate & Epilepsy \\
\hline 5 & 39 & VIII & mild & Trauma & 1954 & Cerebellum & + & + & + & - & - & Nil & Ataxia \\
\hline \multirow{2}{*}{6} & 20 & VIII & severe & Nil & 1960 & $\begin{array}{l}\text { Subarachnoid, } \\
\text { intracerebral }\end{array}$ & + & - & + & - & - & Adequate & Recovery \\
\hline & 21 & VIII & severe & Coughing & 1961 & Subarachnoid & + & 一 & + & - & - & Adequate & Recovery \\
\hline \multirow[t]{2}{*}{7} & 9 & VIII & moderate & Nil & 1947 & Intracerebral & + & - & - & - & - & Nil & Recovery \\
\hline & 23 & VIII & moderate & Nil & 1961 & $\begin{array}{l}\text { Subarachnoid, } \\
\text { intracerebral }\end{array}$ & + & - & + & 一 & - & Adequate & Aphasia (temporary) \\
\hline 8 & 17 & VIII & severe & Trauma & 1958 & $\begin{array}{l}\text { Subarachnoid, } \\
\text { intracerebral }\end{array}$ & + & - & + & - & - & Adequate & Recovery \\
\hline 10 & 14 & VIII & severe & Meningitis & 1957 & $\begin{array}{l}\text { Subarachnoid, } \\
\text { intracerebral }\end{array}$ & + & + & - & - & + & Inadequate & Death \\
\hline 11 & 11 & IX & severe & 'Bleeding phase' & 1961 & Subarachnoid & + & - & + & - & 一 & Adequate & Recovery \\
\hline 12 & 6 & VIII & severe & Trauma & 1953 & Subdural & + & + & - & + & - & Inadequate & $\begin{array}{l}\text { Hemiparesis (slight), } \\
\text { deformity }\end{array}$ \\
\hline 13 & 6 & IX & severe & Nil & 1952 & Intracerebral & + & - & - & 一 & 一 & Nil & Recovery \\
\hline 14 & 3 & VIII & severe & Nil & 1961 & Subarachnoid & + & + & + & - & + & Adequate & Death \\
\hline 15 & 1 & VIII & severe & Trauma & 1950 & Intracerebral & + & + & - & - & - & Nil & Recovery \\
\hline
\end{tabular}

mild, which, for general discussion is included with the former, because there is obvious haemorrhagic disease in contrast to the more occult condition of mild haemophilia.

MILD HAEMOPHILIA Factor level is $3-30 \%$. Coagulation time is normal. Abnormal bleeding is associated with obvious trauma, tooth extraction, operation, or local pathology. Haemarthroses are uncommon, occurring after definite injury to limbs.

Fifteen $(13.8 \%)$ of the 109 haemophiliacs experienced between them 19 episodes of proven or probable intracranial haemorrhage (Table II). Direct evidence of bleeding was obtained from examination of cerebrospinal fluid on three occasions and at operation or necropsy on six. A diagnosis of probable intracranial haemorrhage was made on clinical grounds in the remaining 10 episodes, in which seven patients had abnormal electroencephalographic tracings. All cases since 1958 (except the second episode of case 3 ) were observed personally and several have been briefly described elsewhere (Kerr, 1963). Details of the remainder were obtained from hospital records or the attending physician with the exception of the first episode of case 8 of which the mother, a trained nurse, supplied information.

\section{ILLUSTRATIVE CASE HISTORIES}

This is a case of probable intracerebral and subarachnoid haemorrhage in a severe haemophiliac.

CASE 4 A clerk aged 43 with severe factor VIII deficiency had complained of right-sided headache for five days. Then over a few hours before admission to hospital he developed weakness of the right side and difficulty in speaking. In hospital he was fully conscious and had nominal aphasia. No history or external evidence of head injury could be obtained. Examination revealed signs of meningism, unequal pupils, right facial palsy, right spastic hemiparesis, and a bilateral extensor plantar response. Temperature was $99 \cdot 6^{\circ} \mathrm{F}$, blood pressure $140 / 80 \mathrm{~mm} . \mathrm{Hg}$. A skull radiograph showed no fracture or pineal shift. An electroencephalogram recorded markedly abnormal activity in the left temporal region. Therapy was commenced with plasma, intravenous antibiotics, and oral anticonvulsants. Shortly afterwards focal fits developed involving the right side of the face and right arm. These were controlled with difficulty over the following week. Thereafter the patient showed rapid improvement and was discharged from hospital four 
weeks after the initial episode, free from seizures and with diminished temporal region activity in electroencephalograms. Anticonvulsants were suspended but focal fits recommenced several days later to be replaced by frequent attacks of temporal lobe epilepsy characterized by olfactory aura, loss of speech, and generalized weakness, but not unconsciousness. Over the next two years fits became less frequent and anticonvulsants were finally withdrawn after a further year. Serial electroencephalographic tracings indicated a residual left temporal abnormality. The patient was forced to give up clerical employment because of a persistent receptive disorder of language function comprising acalculia, inability to concentrate, forgetfulness, and euphoria.

Intracerebral and subarachnoid haemorrhage following meningitis in a severe haemophiliac is illustrated by the next case.

CASE 10 A schoolboy aged 14 with severe factor VIII deficiency two days after developing an upper respiratory tract infection complained of severe generalized headache, became stuporose, and had several generalized convulsions. On admission he was comatose and had proptosis of the left eye and marked signs of meningism. Temperature was $103^{\circ} \mathrm{F}$. Lumbar puncture revealed turbid cerebrospinal fluid containing organisms (meningococci). After two days' treatment with intravenous antibiotics and plasma the patient was much improved and sterile fluid was obtained at a second lumbar puncture. Seven days after admission he complained of mild frontal headache and neck stiffness. There was no fever and a third lumbar puncture produced xanthochromic and sterile fluid. Three days later severe pain in the buttocks and upper thighs, and urinary retention heralded the onset of spinal cord compression which progressed to complete flaccid paraplegia with diminution of pinprick sensation to the level of T4. Three weeks later the patient gradually became comatose and died.

At necropsy blood clots were found in the left temporal, parietal, and occipital lobes. Bleeding had not been entirely recent as the clots were beginning to undergo organization. There was clotted blood in the subarachnoid space at the base of the brain and no evidence of active infection. Blood clot extended from the lower cervical to sacral region in the spinal subarachnoid space but the cord was not sectioned to determine the presence of intramedullary bleeding. There were also signs of haemorrhage related to the needle track through spinal muscles.

Case 14 demonstrates subarachnoid haemorrhage in a severe haemophiliac.

CASE 14 A child aged 3 with severe factor VIII deficiency, after a series of traumatic and apparently spontaneous haemorrhages, was investigated because of unusual irritability and anorexia. He was afebrile and no objective abnormality was found. Six days later vomiting and fever $\left(100-102^{\circ} \mathrm{F}\right.$.) commenced and examination revealed slight neck rigidity and Kernig's sign. A skull radiograph and an electroencephalogram were normal. For 12 day\$ the child improved on antibiotic therapy but then, ove 5 48 hours, became drowsy, developed papilloedema, ha generalized convulsions, and died in coma. Lumba $\overline{5}$ puncture 24 hours before death revealed xanthochromie fluid, but the pressure was not measured.

Internal hydrocephalus was found at necropsy witß blood clot occluding the subarachnoid space in the regioñ of the pons and mid-brain. There was also evidence of earlier subarachnoid haemorrhage in the posterior fossa.:-

Recurrent intracranial haemorrhage in a severe haemophiliac is shown by the following case.

CASE 6 A 19-year-old clerk with severe factor VII deficiency developed marked signs of meningism anç papilloedema after a bout of coughing. There was no clinical or electroencephalographic evidence of a focaP lesion, and except for persistent retinal exudates, the patient recovered on plasma therapy. Six months latere for no apparent cause, signs of meningeal irritatiors returned, together with right homonymous hemianopia A distinct bruit was detected in the left supra-orbitah region, and electroencephalography recorded abnormaN activity in the left temporal area. In view of the possibility of a vascular anomaly, with surgery offering the only admittedly remote, chance of survival, angiography was attempted via catheterization of each radial artery in turn. Only the vertebral system could be visualized, 进d the procedure was not followed by complications However, the patient recovered completely and all signe. of clinical and electroencephalographic abnormality disappeared in six weeks. One year later there was third episode, again after coughing, which followed $\vec{a}^{+}$ course similar to the first but without retinal involvement?

Chronic subdural haematoma in a severe haemo philiac is illustrated by case 12 .

CASE 12 A 6-year-old boy with severe factor VII $\overrightarrow{\mathrm{E}}$ deficiency was knocked down by a horse, receiving several lacerations on the right side of the head. Six weeks later he became drowsy and was admitted wit|p? signs of meningeal irritation, papilloedema, and right hemiparesis. There was no radiological evidence of fracture and lumbar puncture yielded xanthochromie fluid under normal pressure (despite papilloedema) Under inadequate cover of blood and plasma a large amount of clotted blood was removed through burr holes in the left parietal and temporal bones. There was some improvement in the general level of consciousness but as hemiplegia remained complete left temporal craniotomy was performed and more solid clot removed from ove믄 the temporal and parietal lobes. A stormy period followed. with bleeding from the operative site, focal and general 0 ized fits, wound infection, and eventual skin grafting of scalp defect. The child was discharged from hospitap seven months after operation with some residual right sided weakness, of which only minimal signs remained nine years later. 
CLINICAL FEATURES

FREQUENCY, AGE INCIDENCE, AND MORTALITY Reported frequency varies with the aim of each investigation. Where central nervous system haemorrhage was specifically examined in a group of haemophiliacs the incidence was relatively high: from $6.3 \%$ (Silverstein, 1960) to $13.8 \%$ in the present series. Where laboratory characterization was the main objective the recorded incidence was low: from $0.6 \%$ (Sjølin, 1960) to $1.9 \%$ (Niewiarowski, Cetnarowicz, Latallo, and Sablinski, 1960) and it is estimates of this order that presumably lead to the usual text-book statement that intracranial haemorrhage is rare in haemophilia.

Intracranial haemorrhage accounted for seven out of 221 admissions to hospital among 70 haemophiliacs of this series over a three-year period (Kerr, 1963). This was a more frequent indication for admission than, for instance, epistaxis or the need for an operation.

The mean age of all patients at the time of haemorrhage was 23 years; of those with severe haemophilia, 16 years (range from 1 to 47 years) and, for mild haemophiliacs, 46 years (range from 39 to 50 years). The mean age of 91 severe haemophiliacs in the parent series was 14.5 years, and of 17 mildly affected patients, 34 years. Because a proportion of child haemophiliacs attended a nearby children's hospital and a positive attempt had been made to discover uninvestigated adults, there was some bias towards older patients joining the series. Nevertheless the evidence suggests that intracranial haemorrhage is a potential risk to severe haemophiliacs at all ages and to mild haemophiliacs in their fourth or fifth decade.

Five $(33 \%)$ of the 15 patients died from intracranial haemorrhage. This is currently the major cause of death among haemophiliacs in New South Wales, accounting for $11(38 \%)$ of 29 deaths during the last decade. Previous estimates of mortality have been around $70 \%$ (Imhof, 1951; Silverstein, 1960).

\section{AETIOLOGY}

TYPE AND DEGREE OF COAGULATION FACTOR DEFICIENCY There is nothing to suggest association between a particular coagulation defect and intracranial bleeding, although Owren (1953) described a remarkable family with factor VII deficiency where 10 out of 12 affected members were said to have died or suffered from cerebral haemorrhage. Douglas and McAlpine (1956) suspected a relationship with factor IX deficiency. In the present series, $25 \%$ of episodes occurred in patients with factor IX deficiency which is to be expected with a $4: 1$ frequency ratio for, respectively, factor VIII and factor IX deficiency in New South Wales (Kerr, 1963).

Severe haemophilia undoubtedly creates a favourable situation for persistent bleeding from blood vessels breached by some disruptive force often so slight that its nature was not detectable in seven out of 15 episodes. The risk of precipitating haemorrhage in mild haemophiliacs appeared much less and there was an obvious preceding cause in three out of four cases.

TRAUMA Intracranial bleeding followed a definite head injury on five occasions, but only case 5, involved in a car accident, lost consciousness. Contrecoup laceration of the occipital cortex was caused by a sharp localized blow on the forehead of case 6. Two severe haemophiliacs had a moderate degree of injury (case 12, knocked over by a horse; case 15 , fell off a chair) but the third, case 8 , had been pillow-fighting with his haemophilic brother and received only a slight blow on the head.

INFECTION Meningococcal meningitis preceded fatal bleeding in case 10. Case 12 developed purulent meningitis two years after craniotomy, which swiftly responded to antibacterial therapy without suggestion of associated haemorrhage.

\section{CEREBRAL PATHOLOGY}

One patient (case 1) had hypertension, angina pectoris, and electrocardiographic evidence of ischaemic heart disease before he died from a ruptured vertebral aneurysm. Other patients had no evidence of vascular, cardiac, or renal disease, nor of an unrelated intracranial lesion. The transient intracranial bruit heard in case 6 was probably the result of a vessel being distorted by intracerebral haematoma rather than evidence of congenital vascular abnormality.

\section{CHANGES IN INTRACRANIAL PRESSURE}

Case 6 was admitted to hospital with bilateral peri-orbital haematoma and signs of meningism 24 hours after developing a harsh unproductive cough. His third episode was also precipitated by coughing.

The marked changes in intracranial dynamics that accompany headache from contact with nitroglycerine (first episode of case 3 ) have been discussed in detail elsewhere (Kerr, 1961). The relationship to haemorrhage remains conjectural, although bleeding occurred when the patient had temporarily lost tolerance to nitroglycerine and the physiological effects were correspondingly exaggerated. 


\section{'BLEEDING PHASE'}

The closely observed onset of subarachnoid haemorrhage in case 11 , lying quietly in bed and simultaneously bleeding at numerous other sites without evidence of any preceding trauma, illustrates a malignant example of this unexplained phenomenon. An almost identical case has been reported (Brachfeld and Hrodek, 1958).

\section{SITE OF BLEEDING AND SIGNS AND SYMPTOMS}

On five occasions the site of bleeding was evident at operation or necropsy. In the remainder it was difficult and in some cases quite arbitrary to localize haemorrhage from available clinical information. However, final verdicts on the site of bleeding in all 19 episodes were as follows: intracerebral, five; with subarachnoid extension, six, and with subdural extension, one; subarachnoid, four; mid-brain, one; subdural, one, and cerebellum, one.

Signs and symptoms did not differ from those found when bleeding occurs at similar sites in people with normal blood coagulation. There was alteration in the level of consciousness in 14 episodes, and pain in the neck and back were major complaints on five of the 11 occasions when meningism was noted. Focal or generalized fits occurred during seven episodes.

\section{INVESTIGATIONS}

A skull radiograph was taken on all patients admitted to hospital. None showed evidence of bony fracture, shift of a visible pineal gland, or other abnormality.

Lumbar puncture was carried out on nine occasions with precipitation of spinal subarachnoid bleeding in one patient (case 10) as the sole complication. After this, lumbar puncture was avoided unless absolutely indicated, as in case 14, whose condition worsened without any clinical evidence of the underlying pathology. Pneumoencephalography was satisfactorily undertaken on one patient (case 5).

The diagnostic limitations of electroencephalography are well known and so it was in this series. Nevertheless, the technique was valuable in detecting an abnormal focus of activity in 10 episodes and in following its evolution with serial recordings during therapy.

Cerebral angiography was attempted once via the radial artery in case 6 .

\section{TREATMENT AND RESULTS}

Concentrated sources of coagulation factors were not available until after the series was completed and deep frozen plasma was used to supply factors
VIII and IX. Plasma was given in volumes calculated $\mathbb{Q}$ to raise and maintain the patients' factor level to 15 to $20 \%$ of normal (termed 'adequate' replacement $\stackrel{\text { }}{\subseteq}$ therapy in Table II). In the absence of extensive 0 tissue damage this is probably the lowest level at $C$ which haemostatically useful clotting occurs. Infusion of plasma was continued for at least a week $\frac{\overrightarrow{0}}{\overline{0}}$ after there was evidence that bleeding had ceased. Patients were kept at rest for three to four weeks: after the initial episode and then gradually assisted to their former state of activity. Oral anticonvulsant $\bar{O}$ drugs were given to all who had seizures and to 흐 others in the latter part of the series who had $\frac{\bar{m}}{a}$ intracerebral haemorrhage. Maintenance doses were $\mathbb{\varnothing}$ continued for a year after the last fit. Great care was taken to prevent physical damage during fits.

During the period when lumbar puncture was $\vec{\circ}$ avoided there were five patients with signs of $\overrightarrow{\vec{\omega}}$ meningeal irritation in whom the diagnosis of ${ }_{o}^{\omega}$ meningitis could no be excluded on clinical grounds. $\overline{\bar{J}}$ All were given an appropriate combination of $\frac{7}{0}$ antibiotic drugs and the subsequent course usually is favoured a diagnosis of haemorrhage rather than i infection. However, it is possible that case 7 had $\vec{\sigma}$ bacterial meningitis that responded to antibiotics, $\sigma$

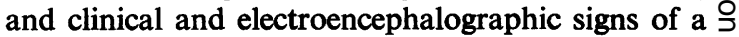
focal lesion were due to an area of cerebritis rath than haematoma.

The fact that four patients had probable intrat cranial haemorrhage during childhood and surviveg. $\overrightarrow{0}$ a desperate illness without any specific treatmen $\stackrel{\circ}{+}$ emphasizes the difficulty of objectively observing the 0 effects of therapy. But it is certain that removal of subdural haematoma averted death in case 12 , and rapid improvement in several other patients coincident with adequate factor replacement therapy suggested that bleeding had been arrested.

Three of five fatal episodes were probably $\overrightarrow{\overrightarrow{0}}$ inaccessible to any form of therapy, but it is possible that fatal extension of bleeding would have been avoided had concentrated factor VIII been available in the management of cases 10 and 14. Necropsy on four patients showed that vital centres in the midand hind-brain were directly destroyed by haemorrhage or by compression due to tonsillar herniation through the foramen magnum.

Four patients had permanent incapacitating disability from intracranial haemorrhages as follows: 욱 temporal lobe epilepsy and loss of abstract skills (case 4), cerebellar ataxia (case 5), generalized fits (case 9), and right-sided weakness (case 12).

\section{DISCUSSION}

There is objective evidence that improved therapy is 0 increasing the life span of severe haemophiliacs 0 
(Kerr, 1962; Jorpes and Ramgren, 1962) which, together with the age distribution in the present series, indicates that intracranial haemorrhage is likely to be a problem at all ages and not merely among young patients as suggested by past experience (Silverstein, 1960). As control of bleeding at other sites becomes progressively more reliable intracranial haemorrhage will probably remain the major barrier to the severe haemophiliac achieving a life expectancy comparable to the general male population.

The position is not so clear in mild haemophilia. Those seen in hospital are usually selected because of some dramatic bleeding that did not respond to local measures and ultimately led to laboratory studies. Mild haemophiliacs discovered in New South Wales (Kerr, 1962) and Finland (Ikkala, 1960) have an age distribution similar to that of the normal male population and this, together with evidence from the present series, suggests a lesser risk of intracranial haemorrhage, possibly increasing slightly with advancing age if significant precipitating causes are encountered.

Trauma has been recognized as the outstanding cause of intracranial haemorrhage ever since 1819 when Wilson described two haemophiliacs who died after falls 'in which they received blows on the head not sufficiently severe to have produced much mischief in a sound state of the system, but which in them was followed by extravasation of blood within the cranium' (Lane, 1840). Definite trauma occurred in $45 \%$ of cases reviewed by Silverstein $(1960)$ and in five $(26 \%)$ episodes in the present serie'. But major head injury is not necessarily followed by haemorrhage. Enquiry among all 109 haemophiliacs revealed that 13 had experienced such an injury without intracranial complication (Table III). All but three were rendered unconscious. Case 7 is noteworthy for he had probable intracranial haemorrhage at the age of 9 and again at 23 , but when 16 was knocked unconscious in a fairground boxing booth without apparent ill effect. Case 26, a notorious street fighter with factor IX deficiency, had a promising career as a professional boxer cut short not from traumatic bleeding but by inability to breathe through a flattened nose.

The inconsistent relationship between head injury and bleeding, together with absence of any detectable preceding incident in $50 \%$ of episodes, underlines the futility of excessive restriction in physical activity, especially as this is incompatible with useful psycho-social development of young haemophiliacs. In 1868 the British Medical Journal strongly advised the haemophilic Duke of Albany to refrain from the usual princely pursuits and support the arts and music. The Duke followed this advice, although handicapped by haemarthrosis of the knee until, ironically, while watching a floral festival at Cannes he fell, struck his head, and died shortly afterwards from intracranial haemorrhage (Brit. med. J., 1884). However, the dangers are such that all haemophiliacs, severe or mild, should be encouraged to avoid rough body-contact sports and similar pastimes. It may be difficult to convince the mildly affected. For instance, none of the four boxers listed in Table III had required medical attention for injury received during a total of 144 bouts. Yet none was a stranger to hospital, having between them been previously admitted on nearly 50 occasions (three out of four had active duodenal ulceration).

The dangers of sudden alteration in intracranial tension are illustrated by cases in which coughing, or contact with nitroglycerine, preceded haemorrhage. A severe haemophiliac reported by Paillas, Boudouresques, and Tamalet (1948) developed fatal intracranial bleeding after performing Queckenstedt's manoeuvre on himself by partial strangulation during self-designed exercises for an arthritic cervical spine.

Congenital or acquired cerebrovascular lesions

TABLE III

MAJOR HEAD INJURY WITHOUT INTRACRANIAL HAEMORRHAGE

\begin{tabular}{|c|c|c|c|c|c|}
\hline $\begin{array}{l}\text { Case } \\
\text { No. }\end{array}$ & $\begin{array}{l}\text { Age } \\
\text { (yr.) }\end{array}$ & $\begin{array}{l}\text { Severity of } \\
\text { Factor } \\
\text { Deficiency }\end{array}$ & Nature of Head Injury & Lost Consciousness & Remarks \\
\hline
\end{tabular}

\begin{tabular}{|c|c|c|c|c|c|c|}
\hline $\begin{array}{l}7 \\
16 \\
17 \\
18 \\
19 \\
20 \\
21 \\
22 \\
23 \\
24 \\
25 \\
26 \\
27\end{array}$ & $\begin{array}{l}16 \\
32 \\
21 \\
28 \\
34 \\
32 \\
32 \\
28 \\
28 \\
26 \\
26 \\
20 \\
18\end{array}$ & $\begin{array}{l}\text { VIII } \\
\text { VIII } \\
\text { VIII } \\
\text { VIII } \\
\text { IX } \\
\text { IX } \\
\text { IX } \\
\text { VIII } \\
\text { VIII } \\
\text { IX } \\
\text { VIII } \\
\text { IX } \\
\text { VIII }\end{array}$ & $\begin{array}{l}\text { moderate } \\
\text { severe } \\
\text { severe } \\
\text { moderate } \\
\text { mild } \\
\text { mild } \\
\text { mild } \\
\text { mild } \\
\text { mild } \\
\text { mild } \\
\text { mild } \\
\text { mild } \\
\text { mild }\end{array}$ & $\begin{array}{l}\text { Boxing } \\
\text { Fighting } \\
\text { Motorcycle accident } \\
\text { Hit on head with } 8 \mathrm{lb} \text {. hammer } \\
\text { Fighting } \\
\text { Boxing } \\
\text { Boxing } \\
\text { Fighting } \\
\text { Blown up on active service } \\
\text { Hit on head with bottle } \\
\text { Fell off horse } \\
\text { Boxing (professional) } \\
\text { Tackled at rugby }\end{array}$ & $\begin{array}{l}\text { Yes } \\
\text { Yes } \\
\text { Yes } \\
\text { No } \\
\text { Yes } \\
\text { No } \\
\text { No } \\
\text { Yes } \\
\text { Yes } \\
\text { Yes } \\
\text { Yes } \\
\text { Yes } \\
\text { Yes }\end{array}$ & $\begin{array}{l}\text { Boxed } 10 \text { bouts } \\
\text { Intra-abdominal haemorrhage } \\
\text { Extensive lacerations, fractured femur } \\
\text { Extensive haematoma and lacerations } \\
\text { Boxed } 14 \text { bouts } \\
\text { Boxed } 80 \text { bouts } \\
\text { Fractured tibia } \\
\text { Scalp laceration } \\
\text { Boxed } 40 \text { bouts } \\
\text { Scalp haematoma }\end{array}$ \\
\hline
\end{tabular}


increase the risk of haemorrhage in all persons, but intracranial infection, the 'bleeding phase', and cerebral neoplasm (case 6 of Silverstein, 1960) are additional hazards in haemophilia.

The exclusion of intracranial infection is a frequent diagnostic problem as $11(58 \%)$ episodes were accompanied by signs of meningeal irritation due to primary subarachnoid haemorrhage or extension of blood into the ventricles from an intracerebral source. More important, during the same period, two severe haemophiliacs had proven bacterial meningitis. Differentiation may be impossible on clinical grounds and, although 'blind' antibiotic therapy combined with plasma proved a satisfactory form of management in the present series it is obviously more desirable to examine the cerebrospinal fluid in such cases. It is true that nothing more serious than occasional external bleeding has complicated 40 reported lumbar punctures (Silverstein, 1960) and eight in the present series, but one episode of spinal canal haemorrhage (case 10) is sufficient to emphasize completely reliable factor replacement therapy during the procedure.

Even more hazardous is cerebral angiography via percutaneous puncture of carotid arteries. This has caused fatal arterial bleeding in one severe haemophiliac (Simpson and Robson, 1960) although another patient with a less marked haemorrhagic tendency survived the procedure (Silverstein, 1960). Recently right carotid angiography has been performed without incident on a haemophilic boy under cover of concentrated factor VIII in order to locate intracerebral haemorrhage before operation (Potter, 1963). Simpson and Robson emphasized the value of angiography in localizing supratentorial lesions when describing another haemophiliac in whom a subdural blood clot could not be completely removed through inability to define the extent of bleeding at operation. Angiographic techniques involving catheterization or retrograde injection of radio-opaque material into the brachial or radial arteries are less dangerous as subsequent arterial bleeding can be more easily controlled than that following carotid puncture. However, adequate visualization of the intracranial circulation is technically difficult utilizing peripheral arteries, and the more informative procedure of carotid angiography is indicated if skilfully performed under optimal factor replacement therapy.

The most common situation for haemorrhage in reported cases is sub- or extradural (Silverstein, 1960). This reflects case selection by rigid proof of intracranial bleeding at necropsy because acute subdural bleeding is invariably fatal, as in case 2 and in cases reported by Paillas et al. (1948), Shannon (1959), and Simpson and Robson (1960). An intra- cerebral source was proved or suspected in $11(60 \%$ episodes in the present series. If bleeding at this sits did not prove fatal within several hours of onseef (three cases) the outlook for survival appeare favourable (eight cases). Bleeding largely confined tog the subarachnoid space with absent or minimal signes of cerebral involvement caused one death (case 14). through obstruction of basal cisterns and acute hydrocephalus, but generally the chance of complete recovery is good, as in cases 6 and 11, and in five ou霄 of six episodes confirmed by lumbar puncture i severely hacmophilic children reported by Brachfelf and Hrodek (1958).

Preventive measures depend on educating haemo philiacs and their parents in the nature of pres disposing incidents and warning symptoms thefe warrant immediate assessment in a suitabl $\vec{\Phi}$ equipped centre. Coagulation factor concentrates. are more effective than plasma for reaching anf maintaining haemostatic levels in the patients:circulation. Concentrates also preclude the physica difficulties associated with administering large volumes of plasma. Four to six litres of plasma pqu day may be necessary to sustain a factor level around $20 \%$ in a haemophilic adult. The risk of circulatory overloading is considerable and such volumes ar out of the question in older patients with suspect renal or cardiac function. Clinical evidence $\circ$ cerebral oedema was not noted in the present seeies; and agents for lowering intracranial tension not used. Neurological disorders resulting for intracranial bleeding may be dangerous. For instancè convulsions can lead to respiratory obstruction through haemorrhagic infiltration of the tongue an oropharyngeal tissue, and cause traumatic bleedin elsewhere. Falls are likely with disordered gai Joints affected by haemophilic arthritis may be overlooked during acute illness and fixed deformi $\vec{\vartheta}$ can rapidly develop, as in case 12 , who was left wit a complicated type of talipes equinovarus due to the combined effects of paresis, ankle joint fixation, and soft tissue contracture.

Operation must be considered in cases which fa to respond to factor replacement therapy and other conservative measures. Extradural (Jamieson, 1954) and chronic subdural haematoma (Van Crevel\&, Hoorweg, and Stijn, 1957; Hartmann and Diamon 1957) have been satisfactorily evacuated from sevege haemophiliacs under cover of plasma, but cons valescence was marked by many complications each case, as with the craniotomy in case 12 . $\overline{\text { F }}$ contrast no post-operative complications were noted when human factor IX concentrate was used cover removal of subdural haematoma through small lateral craniotomy in an almost moribund infant with factor IX deficiency (Potter, 1963). 
Most attempts to remove intracerebral blood clot through burr holes (Paillas et al., 1948; Jones and Knighton, 1956) or craniotomy (Simpson and Robson, 1960; Silverstein, 1960) have failed. However, Singer and Schneider (1962) have reported successful evacuation of clotted blood from the temporal lobe via frontal craniotomy in a haemophilic infant. Recently, trephine craniotomy as used in general surgical management of intracerebral haematoma (Pennybacker, 1963) proved a satisfactory method for removing blood clot from the frontal lobe of a boy with factor VIII deficiency (Potter, 1963).

Coagulation factor concentrates are essential for achieving haemostasis during major surgery and particularly so with intracranial operations where bleeding can be troublesome enough in persons with normal blood coagulation. Jamieson (1954) has discussed the relative merits of local haemostatic techniques in this situation.

\section{SUMMARY}

Nineteen episodes of proven or probable intracranial haemorrhage occurred in $15(13.8 \%)$ of 109 haemophiliacs, causing five deaths and residual disability in four patients. Trauma, changes in intracranial tension, intracranial infection, and the 'bleeding phase' were predisposing causes in $50 \%$ of cases. It was shown that major head injury is not necessarily followed by haemorrhage. Intracranial bleeding, currently the most common cause of death among haemophiliacs in New South Wales and elsewhere, is a potential risk to severely affected patients at any age and to mild haemophiliacs in the older age groups. The outlook for survival appeared most favourable when bleeding was largely subarachnoid, or when the patient survived the acute stages of intracerebral haemorrhage. Potentially dangerous neuro-diagnostic techniques must be skilfully performed in centres with facilities for reliable coagulation factor replacement therapy. Factor concentrates are superior to plasma in general management and are essential for covering intracranial operations.

I am very grateful to Mr. Richard Gye for helpful criticism of this paper, and to Mr. J. M. Potter, of Oxford, who kindly permitted me to mention two of his cases which he intends to describe more fully elsewhere. Almost all patients were under the care of Professor C. R. B. Blackburn who, with Mr. J. N. Segelov and Dr. O. Appenzeller, provided helpful discussion. Dr. H. Kronenberg performed routine coagulation studies on all patients, and Dr. J. Margolis assayed factor levels in some. The work was done under a grant from the Post-Graduate Medical Foundation of the University of Sydney.

\section{REFERENCES}

Aggeler, P. M., and Lucia, S. P. (1944). J. nerv. ment. Dis., 99, 475. Birch, C. L. (1937). Hemophilia: Clinical and Genetic Aspects, Illinois med. dent. monogr., vol. 1 , no. 4. University of Illinois, Urbana, Ill.

Blombäck, M. (1962). Personal communication.

Brachfeld, K., and Hrodek, O. (1958) Ćs. Pediat., 13, 495.

Brit. med. J. (1868). Leading article. 1, 148.

Creveld, S. Van, Hoorweg, P. G., and Stijn, R. W. (1957). Arch. chir. neerl., 9, 263.

Douglas, A. S., and McAlpine, S. G. (1956). Scot. med. J., 1, 270.

Hartmann, J. R., and Diamond, L. K. (1957). Practitioner, 178, 179.

Ikkala, E. (1960), Scand. J. clin. Lab. Invest., suppl. 46.

Imhof, H. H. (1951). Z. menschl. Vererb.-u Konstit.-Lehre, 30, 466

Jamieson, K. G. (1954). Aust. N.Z.J. Surg., 24, 56.

Jones, R. K., and Knighton, R. S. (1956), Ann. Surg., 144, 1029.

Jorpes, J. E., and Ramgren, O. (1962). Acta med. scand., suppl. 379.

Kerr, C. B. (1961). Brit. J. industr. Med., 18, 47.

, (1962). Aust. Ann. Med., 11, 156.

, (1963).The Management of Haemophilia, Australasian Publishing Co., Sydney.

Lane, S. (1840). Lancet, (1840-41) 1, 185.

Margolis, J. (1961). Brit. J. Haemat. 7, 21.

Niewiarowski, S., Cetnarowicz, H., Latallo, Z., and Sablinski, J. (1960). International Society of Hematology: Proceedings of the 7th Congress, Rome, 1958, vol, 2, p. 965. (publ. 1960).

Owren, P. A. (1953). Amer. J. Med., 14, 201.

Paillas, J. E., Boudouresques, J., and Tamalet, J. (1948). Sem. Hôp. Paris, 24, 432.

Pennybacker, J. (1963). Proc. roy. Soc. Med., 56, 487.

Potter, J. M. (1963). Personal communication.

Shannon, R. (1959). Aust. N.Z.J. Surg., 28, 316.

Silverstein, A. (1960). Arch. Neurol, Psychiat, (Chic.), 3, 141.

Simpson, D. A., and Robson, H. N. (1960). Aust. N.Z. J. Surg., 29, 287.

Singer, R. P., and Schneider, R. C. (1962). Neurology (Minneap.), 12, 293.

Sjølin, K. E. (1960). Haemophilic Diseases in Denmark. Blackwell. Oxford.

Sköld, E. (1944). Acta med. scand., suppl. 150. 